\title{
Analysis on the Potential of the Export Trade of China's Electrical Equipment under the One Belt and One Road Initiative
}

\author{
Taiyi Yang \\ School of Economics and Management, Tongji University, Shanghai 201800, China. \\ 15316701381@163.com
}

\begin{abstract}
This paper takes whether the countries and regions involved in China's electric equipment export trade are covered by "One Belt and One Road Initiative (OBOR)" as the dividing basis. In addition, through the analysis on the export situation of these countries and regions based on trade specialization coefficient (TC), the relevant data indicate that the export trade of electrical equipment between China and the countries covered by OBOR is still in a mutually reinforcing stage. Furthermore, this paper also evaluates the positive influence that China's electrical equipment industry may bring to the countries covered by OBOR as well as its great advantages in trade, and the result shows that China has a great potential for the development of the electric equipment trade under the OBOR. It is suggested that Chinese administration should introduce relevant policies to encourage the export of China's electrical equipment to countries and regions covered by OBOR and actively promote China's electrical equipment exporters to contribute to the strategic market transfer to these countries and regions.
\end{abstract}

Keywords: Electrical equipment export, OBOR, trade specialization coefficient, trade potential.

\section{Introduction}

The establishment of Silk Road Fund that followed the APEC and the support from the relevant investment and financing are of considerable significance to the construction of infrastructure, resource development and industrial cooperation and other issues in the countries or regions covered by OBOR. Power grid construction will be in the leading position for the development of infrastructures, and there will be a lot of financial support for the relevant countries' power grid construction, so China's power equipment trade may have a greater potential of development.

Relevant data showed that China's production capacity of power equipment in 2013 has reached 120 million kilowatts, reaching $60 \%$ in the proportion of the world's production, but China's power production obviously is in a surplus. Therefore, currently, China's electrical equipment enterprises need to use some feasible measures to deal with the remaining capacity, and one of the more important measures is to export them. With the increasing investment in power grid construction in China, various types of power equipment continue to appear, and their international competitiveness is also strengthened. Under the OBOR, there is a wide range of overseas markets for China's electric equipment exporters, and this initiative helps them further enhance their market shares in developing countries. In 2016, China's electrical equipment exports have accounted for more than $42.77 \%$ of total exports, and the relevant trade benefits have not been able to be ignored. Along the countries or regions under OBOR, the majority of them are developing countries and regions with low level of electricity consumption, so there is a huge space for development. With the development of national economy and the increase of electricity consumption, there is a very urgent need to speed up power grid construction. These developing countries are lagging behind and uncompetitive in the research of electric power equipment, so China's export products may have a great competitive advantage.

The implementation of OBOR has made China reach remarkable achievements in the research of electric power equipment, and will make us get a greater development in the future of electrical equipment export trade, which not only can speed up to resolve excess capacity, but also promote the cooperation between China and developing countries, so as to help the developing countries to build infrastructure and strengthen the international relations of China with other countries and to promote the globalization. In the party's 19th National Congress, General Secretary Xi Jinxing also proposed 
that China's comprehensive well-off society construction has entered a decisive stage, and social productivity and social and economic development is still the first priority. As a result, the development of various industries' production and services cannot be separated from the electrical industry's development (Li Chengdu, 2018). Although China's current electrical equipment exports have reached first in the world, there are some obvious problems, such as high degree of market concentration, over-reliance on countries like the United States and some European countries. Under this tone, these phenomena are difficult to reverse recently, which makes the export process susceptible to a variety of factors, such as technical factors. China's electrical equipment's development towards the global market has been hindered to a certain extent, and there are structural and regional imbalances caused by this.

According to China's "Research Report on the Impact of Foreign Technical Trade Measures on China's Electrical Equipment (2016)", in 2016 China's electrical equipment exports reached 125.19 billion U.S. dollars, accounting for $1 / 5$ of the total global electrical equipment exports. This equipment is one of the main export products of China; but China's 39.1\% electrical equipment export enterprises were affected by foreign technical trade measures, resulting in direct losses of 15.21 billion U.S. dollars, accounting for $12.1 \%$ of China's total exports of electrical equipment. China's electrical equipment industry ever encountered more than 22 kinds of foreign technical trade measures, involving all developed countries and most emerging markets. For example, 25 countries of the European Union on August 13, 2005 issued the "Waste Electrical and Electronic Equipment Directive", which significantly increased China's export costs in the field of home appliances and has brought a great impact on China's export trade.

With the implementation of the development strategy of OBOR, the cooperation between China and the countries covered by OBOR has deepened further, especially with 10 ASEAN countries, India, Russia and the five countries of Central Asia (Zheng Gooey, 2014). But there are still a lot of questions worth exploring, such as whether it is possible to meet the relevant requirements for the complementary issues between China's export of electrical equipment and the needs of the OBORinvolved countries and the competition and cooperation relations between OBOR countries and other countries (Qin Lankan, 2016), which have been widely concerned by the industry.

This paper analyzes the export status of electrical equipment of China. Firstly, it analyzes the market information and carries out a targeted analysis and processing according to the difference between OBOR-involved countries and other countries. Then it makes a calculation on the TCs of these two kinds of countries and evaluates the competitive status of electrical equipment based on the calculation results. The results show that the competitiveness of the OBOR-involved countries is basically decreasing, and their trade complementarity with China is gradually increasing. The export of electrical equipment is affected by a variety of factors, such as population size, the export country's gross domestic product and it's TC. Based on these, this paper has established a trade gravity model, and verifies the electrical equipment export trade potentials of OBOR-involved countries and those not covered by OBOR, so as to sum up the characteristics of electrical equipment export trade of the OBOR-involved countries.

This paper can provide a reference for China's enterprises and China in making their market segmentation decisions and choosing markets, and this paper is also of considerable significance for promoting the development and expansion of the relevant markets in the OBOR-involved countries and forming complementary advantages through trade (Kong Qing Feng, Dong Hogweed, 2015)

\section{Literature Review}

\subsection{Progresses in Researches on the Export Trade of Electrical Equipment}

At present, the researches on the export trade of electrical equipment in China are mostly biased towards trade barriers, such as the influence of intellectual property protection on the export of electrical equipment (Lin Haitian, 2012), as well as the impact of EU's WEEE and RoHS directives on the export of China's electrical products and the corresponding countermeasures (Wing Dangling, 
2006). There are a few empirical analyses on other factors, and there are no scholars who made further researches on the trade potential of electrical equipment.

\subsection{Review of the Literature of Trade Gravity Model}

For the trade gravity model, it was initially developed as a prototype under the influence of the law of gravitation and its relevant definitions were obtained based on this. In the law of gravitation, the gravitational force between the objects is positively proportional to the mass sizes of them and is inversely proportional to the distance between them. The trade gravity model appeared in the 60's of the last century, it was originally proposed by scholars Tinbergen et al. based on the law of universal gravitation. Their point of view was that the bilateral trade volume between the two countries is positively proportional to the total economic volume, but inversely related to the distance between them. With the increase of scholars' researches, some scholars put forward the way to expand the trade gravitation model, and add some new parameters to the whole model, such as population quantity, exchange rate, etc., so that it can be applied to the researches on bilateral trade flow effectively.

\section{Distribution of China's Electrical Equipment Export Markets}

China has now exported electrical equipment to most countries in the world. In this paper, it mainly used the data information about China's electrical equipment export in the year of 2016, and its absolute share and relative share were also analyzed. The relevant data in table 1 have shown that, of the countries subject to higher electrical equipment exports of China, the proportions in 4 countries have been higher than 5\%, while the market shares in 14 countries are within the range of $1 \%-5 \%$, and the market shares in other countries are within the $0-1 \%$ range. The first of these is the exports to China's Hong Kong, which are worth 148.221 billion of dollars, accounting for more than $26.79 \%$, and about 1.59 times the share of market in the US, the second-largest export country of China. The total share in top four countries has surpassed $55 \%$, reflecting the relative concentration of exports.

In 2016, in top 30 of China's export countries or regions for electrical equipment, the following 15 countries belong to the OBOR-involved countries: South Korea, Japan, India, Vietnam, Thailand, Malaysia, Indonesia, Russia, the Czech Republic, Pakistan and Hungary and other countries, and the total market share in these countries accounted for $28.47 \%$, and the market share in the above-listed top 10 countries has reached $25.37 \%$, i.e. more than $1 / 4$. Therefore, these 10 countries have been chosen as the typical export countries of China under OBOR. The countries and regions that do not belong to the countries covered by OBOR include 14 countries, including China's Hong Kong, the United States, Britain, Mexico, Australia, Brazil, Italy, Canada, Spain and other countries, while the share in the above-listed top 8 countries has reached $55.23 \%$, i.e. over $50 \%$. Therefore, these 8 countries have been chosen as the typical export countries of China not covered by OBOR. Based on the above data, it can provide a good reference for the analysis on their TCs (Liao Mingzhong, 2015). The detailed market share statistics are shown in the following figure.

\section{Analysis on the TCs of Countries or Regions Covered and Not Covered by OBOR}

China's OBOR can provide more trade opportunities for the countries covered by it, and an international trade can be conducted based on the complementarity of trade between China and these countries (Sun Cajun, 2010). The resource endowment difference is the key factor that determines China's trade complementarity with all these countries, in addition, the improvement and enhancement of market efficiency, trade efficiency, science and education level, infrastructure and macro-economic environment of these countries will help to improve bilateral trade complementarity (Hu Yi, Yan Jilin, Quant Yi, 2017). Currently, China still adheres to the traditional trade model based on resource endowments, so China still has some export advantages. 
In the trade of a country, the TC is an important parameter, which can represent the difference between the import and export trade and the ratio of total import and export within a country, thus reflecting whether the domestic production of a product has a greater advantage when compared to same kind of products supplied by other countries in the global market (Han Yan, 2008). If the export countries covered by OBOR and the countries not covered by OBOR are considered as two partitions, the countries in each partition can be calculated as a whole. By using the export data of each partition from 2007 to 2016, the trade complementarities of the countries covered by OBOR and the countries not covered by OBOR are calculated. The TC can be expressed as:

$$
\mathrm{TC}_{\mathrm{ij}}=\left(\mathrm{X}_{\mathrm{ij}}-\mathrm{M}_{\mathrm{ij}}\right) /\left(\mathrm{X}_{\mathrm{ij}}+\mathrm{M}_{\mathrm{ij}}\right)
$$

Table 1. The market share statistics of China's top 30 export countries for electrical equipment in 2016

\begin{tabular}{ccc}
\hline $\begin{array}{c}\text { Major export countries or } \\
\text { regions }\end{array}$ & $\begin{array}{c}\text { Exports of electrical equipment (100 } \\
\text { million U.S. dollars) }\end{array}$ & $\begin{array}{c}\text { Market shares in export countries } \\
\text { or regions (\%) }\end{array}$ \\
\hline The world & 5531.69 & 100 \\
China's Hong Kong & 1482.21 & 26.79 \\
United States & 931.58 & 16.84 \\
Korea & 337.20 & 6.10 \\
Japan & 326.71 & 5.91 \\
Netherlands & 184.05 & 3.33 \\
India & 169.03 & 3.06 \\
Germany & 152.98 & 2.77 \\
Other Asian countries & 152.76 & 2.76 \\
Vietnam & 120.17 & 2.17 \\
Singapore & 110.68 & 2.00 \\
United Kingdom & 103.91 & 1.88 \\
Thailand & 85.85 & 1.55 \\
Mexico & 81.75 & 1.48 \\
Malaysia & 80.12 & 1.45 \\
United Arab Emirates & 63.77 & 1.15 \\
Australia & 61.38 & 1.11 \\
Brazil & 56.90 & 1.03 \\
Indonesia & 55.46 & 1.00 \\
Russia & 54.37 & 0.98 \\
France & 51.89 & 0.94 \\
Italy & 48.07 & 0.87 \\
Canada & 46.39 & 0.84 \\
Philippines & 42.50 & 0.77 \\
Turkey & 38.42 & 0.69 \\
Czech Republic & 33.56 & 0.61 \\
Spain & 33.51 & 0.61 \\
Pakistan & 33.21 & 0.60 \\
Poland & 32.80 & 0.59 \\
Hungary & 29.36 & 0.53 \\
South Africa & 24.48 & 0.44 \\
\hline Source of & &
\end{tabular}

Source of data: UN Comrade Database

Through the calculation of the TCs of the electrical equipment of the countries covered by OBOR and the countries not covered by OBOR, as can be seen from table 2 below, the TC of China's electrical equipment in this decade is increasing and has reached to a level of $15 \%$ to 2016 . The electrical equipment imports of the countries covered by OBOR and the countries not covered by OBOR are also rising, but their TCs are very limited. It can be seen that China's electrical equipment exports still have a great potential for development. The TCs of the countries or regions not covered by OBOR have remained negative, significantly lower than these countries or regions not covered by OBOR. For the countries covered by OBOR, most of them have a strong demand for infrastructure 
and have shown a clear advantage in the manufacturing aspect. Therefore, in the import and export of electrical equipment, China has a higher complementarity with the countries not covered by OBOR and these countries will still be our main trading partners. Through the observation on the TCs over the years, it can find that the TCs of the countries or regions covered and not covered by OBOR are all in declining, while China is on the rise, which shows that both of them are showing an increasing complementary trend with China in trade. Therefore, in addition to maintaining the markets in countries or regions covered by OBOR, it also needs to enhance the trade with the countries covered by OBOR possessing decreasing TCs. The active exploration for markets is of great significance for China's electrical equipment export.

At present, China's electrical equipment exports are still mainly facing the countries not covered by OBOR. However, along with the implementation of the OBOR, the trade development potential of the countries covered by OBOR has gradually increased (Wang Ting, 2016). At present, China's electrical equipment is in overcapacity, while other countries need the development of high-tech equipment. Judging from China's TCs, China will have a lot of development space to form an advantage about the complementarity with other countries. If the current opportunity can be grasped to improve the high-tech degree of China's electrical equipment and to establish friendly relations of cooperation with other countries and adhere to the in-depth implementation of OBOR development initiative, it will be conducive to China's electrical equipment exports.

Table 2. Analysis on TCs of electrical equipment export

\begin{tabular}{|c|c|c|c|c|c|c|c|c|c|}
\hline Year & $\begin{array}{l}\text { China's } \\
\text { electrical } \\
\text { equipment } \\
\text { exports } \\
(100 \\
\text { million } \\
\text { U.S. } \\
\text { dollars })\end{array}$ & $\begin{array}{l}\text { China's } \\
\text { electrical } \\
\text { equipment } \\
\text { imports } \\
(100 \\
\text { million } \\
\text { U.S. } \\
\text { dollars })\end{array}$ & $\begin{array}{c}\text { Exports of } \\
\text { countries } \\
\text { covered } \\
\text { by OBOR } \\
(100 \\
\text { million } \\
\text { U.S. } \\
\text { dollars })\end{array}$ & $\begin{array}{c}\text { Imports of } \\
\text { countries } \\
\text { covered } \\
\text { by OBOR } \\
(100 \\
\text { million } \\
\text { U.S. } \\
\text { dollars })\end{array}$ & $\begin{array}{c}\text { Exports of } \\
\text { countries } \\
\text { not } \\
\text { covered } \\
\text { by OBOR } \\
(100 \\
\text { million } \\
\text { U.S. } \\
\text { dollars }) \\
\end{array}$ & $\begin{array}{c}\text { Imports of } \\
\text { countries } \\
\text { not } \\
\text { covered } \\
\text { by OBOR } \\
(100 \\
\text { million } \\
\text { U.S. } \\
\text { dollars }) \\
\end{array}$ & $\begin{array}{c}\text { TCs of } \\
\text { China's } \\
\text { electrical } \\
\text { equipment }\end{array}$ & $\begin{array}{l}\text { TCs of the } \\
\text { electrical } \\
\text { equipment } \\
\text { of the } \\
\text { countries } \\
\text { covered by } \\
\text { OBOR }\end{array}$ & $\begin{array}{l}\text { TCs of the } \\
\text { electrical } \\
\text { equipment } \\
\text { of the } \\
\text { countries } \\
\text { not } \\
\text { covered by } \\
\text { OBOR }\end{array}$ \\
\hline 2007 & 3003.066 & 2568.225 & 4411.533 & 3544.687 & 5946.614 & 7253.959 & 0.078 & 0.109 & -0.099 \\
\hline 2008 & 3420.833 & 2665.149 & 4485.413 & 3868.086 & 6175.389 & 7478.458 & 0.124 & 0.074 & -0.095 \\
\hline 2009 & 3010.990 & 2437.561 & 3808.015 & 3210.835 & 5152.347 & 6497.543 & 0.105 & 0.085 & -0.115 \\
\hline 2010 & 3887.550 & 3142.825 & 4790.168 & 4079.789 & 6227.947 & 8002.873 & 0.106 & 0.080 & -0.125 \\
\hline 2011 & 4457.567 & 3509.543 & 5044.518 & 4431.203 & 6654.217 & 8693.079 & 0.119 & 0.07 & -0.133 \\
\hline 2012 & 4873.225 & 3815.210 & 5229.302 & 4803.220 & 6647.909 & 8736.555 & 0.122 & 0.042 & -0.136 \\
\hline 2013 & 5612.883 & 4394.175 & 5476.329 & 5040.128 & 6948.996 & 9100.090 & 0.122 & 0.041 & -0.134 \\
\hline 2014 & 5709.245 & 4243.195 & 5545.020 & 5166.088 & 7280.236 & 9645.816 & 0.147 & 0.035 & -0.140 \\
\hline 2015 & 5943.254 & 4286.943 & 5165.185 & 4704.382 & 7117.166 & 9615.605 & 0.162 & 0.047 & -0.149 \\
\hline 2016 & 5531.689 & 4128.794 & 4623.366 & 4275.745 & 7178.521 & 9724.860 & 0.145 & 0.039 & -0.151 \\
\hline
\end{tabular}

\section{Model Building}

Based on the calculation of the TCs in the electric equipment markets, China and the countries covered by OBOR or the countries not by OBOR can complement each other effectively. Based on this, we can analyze some factors affecting the exports of China's electrical equipment and design the suitable trade gravity model, so as to effectively determine the impact of such factors on the trade potential of the countries covered by OBOR.

\subsection{Setting of the Initial Model}

In the traditional gravity model of $\mathrm{T}=\left(\mathrm{A}^{*} \mathrm{Yi}^{*} \mathrm{In}\right) / \mathrm{rij} 2, \mathrm{~T}$ represents trade volume, $\mathrm{Yi}$ and $\mathrm{In}$ represent the GDP of country I and J and raj represents the distance between these two countries. In this model, trade volume is positively proportional to the GDPs of these two countries but is inversely proportional to their distance. Then some scholars regard the exports as the explained variable, and some scholars regard the bilateral GDP and the distance between the two as explanatory variables (Lin Jian et al., 2008). According to the specific characteristics of the current electrical equipment industry, in this paper, the exchange rates and the TCs of the electrical equipment of the export countries are used as explanatory variables, and whether the export countries have established 
technical barriers for electrical equipment and whether the countries are covered by OBOR are regarded as dummy variables. The results are as shown in the following table.

Table 3. Names and meanings of explanatory variables and the reasons for selection and the predictive symbols

\begin{tabular}{|c|c|c|c|}
\hline $\begin{array}{l}\text { Name of } \\
\text { variables }\end{array}$ & Meanings & Reasons for selection & $\begin{array}{c}\text { Predictive } \\
\text { symbols }\end{array}$ \\
\hline EXPORTit & $\begin{array}{l}\text { China's exports of electrical } \\
\text { equipment to country } \mathrm{i} \text { in the year } \\
\text { of } t\end{array}$ & $\begin{array}{l}\text { The exports can effectively represent the scale of } \\
\text { exports }\end{array}$ & \\
\hline GDPit & $\begin{array}{l}\text { GDP of trade country } i \text { in the year } \\
\text { of } t\end{array}$ & $\begin{array}{l}\text { It can represent the total value of its economic } \\
\text { scale. If the economic scale is large, it means that its } \\
\text { import capacity is stronger, and the bilateral trade } \\
\text { flow will be greater (Bi Yanru et al., 2010) }\end{array}$ & + \\
\hline EXRit & $\begin{array}{l}\text { The average exchange rate of } \\
\text { country i's currency to RMB in } \\
\text { the year of } t\end{array}$ & $\begin{array}{l}\text { It represents the states of two parties in the } \\
\text { international financial market. This article adopts the } \\
\text { indirect quotation method. If the exchange rate rises, } \\
\text { Chinese currency will appreciate and China's exports } \\
\text { decreased. }\end{array}$ & - \\
\hline POPit & $\begin{array}{l}\text { The population of trading country } \\
\qquad \mathrm{i} \text { in the year of } \mathrm{t}\end{array}$ & $\begin{array}{l}\text { It represents the spending power of the trade country. } \\
\text { The larger the population is, the larger the consumer } \\
\text { market, the greater the volume of China's exports, but } \\
\text { as a result, China's consumption will raise and the } \\
\text { foreign trade decreases. }\end{array}$ & Unknown \\
\hline DISTi & $\begin{array}{l}\text { Straight geographic distance } \\
\text { between trade country i and } \\
\text { China }\end{array}$ & $\begin{array}{c}\text { The length of the distance determines the level of the } \\
\text { cost of goods transported. The greater the distance is, } \\
\text { the greater the barriers between the bilateral trade } \\
\text { countries }\end{array}$ & - \\
\hline TCit & $\begin{array}{l}\text { TC of the trade country } i \text { in the } \\
\text { year of } t\end{array}$ & $\begin{array}{c}\text { Within the range of }(-1,1) \text {, the increase of the TC } \\
\text { indicates that it is more competitive and less } \\
\text { dependent on exports }\end{array}$ & - \\
\hline BLi & $\begin{array}{l}\text { Whether the trade country } i \text { has } \\
\text { set a barrier for the export of } \\
\text { China's electrical equipment. } \\
\text { Positive is expressed as } 0 \text {, } \\
\text { negative is expressed as } 1 \text {. }\end{array}$ & $\begin{array}{l}\text { The characteristics of technical barriers to trade are } \\
\text { manifested in some hidden means, which will bring } \\
\text { barriers on the foreign trade of electrical equipment } \\
\text { of China (Zeng Zhaorui et al., 2017) }\end{array}$ & - \\
\hline $\mathrm{BRi}$ & $\begin{array}{l}\text { Whether the trade country i is } \\
\text { covered by OBOR. Positive is } \\
\text { expressed as } 0 \text {, negative is } \\
\text { expressed as } 1 .\end{array}$ & $\begin{array}{l}\text { China needs to develop a deeper cooperation with the } \\
\text { countries covered by OBOR and takes the advantage } \\
\text { of its manufacturing industry to carry out the relevant } \\
\text { cooperation, which will also stimulate China's import } \\
\text { demand }\end{array}$ & Unknown \\
\hline
\end{tabular}

According to the above analysis, the initial model of the export of electrical equipment is set as:

$\log$ (export) $=\mu 1+\mu 2 *$ tic $+\mu 3 * \log$ (pop) $+\mu 4 * \log$ (gap) $+\mu 5 * \log$ (ear) $+\mu 6^{*} \log$ (dist.) $+\mu 7 * \mathrm{br}+\mu 8 * 1 \mathrm{~b}$.

\subsection{Sample Selection and Data Source}

For collecting the basic data for building the model, 10 countries or regions covered by OBOR and 8 countries or regions not covered by OBOR are selected, that is, a total of 18 countries (and regions). The panel data from 2013 to 2016 are used as samples with a sample capacity of 72 , and the condition of estimator $\mathrm{n} \geq 3(\mathrm{k}+1)$ is also met, it can be seen that China's electrical equipment exports to the above-mentioned countries account for more than $80 \%$, which is representative.

According to the "Harmonized Commodity Description and Coding System", the electrical equipment studied in this paper is HS85 (motor, electrical equipment and parts, recorder and sound reproducer, television images and sound recording and reproducing parts and accessories).

According to the relevant statistics, China's electrical equipment exports have basically reached billion-dollar level. Each country's current GDP can be expressed with a unit of trillion dollars, and population size can be expressed with a unit of million people. In addition, the determination of 
distance between China and other trading countries requires a standard approach, for example, it can use the direct space between the two countries to express the distance. Typically, the direct distance between Beijing and the capital of each country can be used (in a unit of kilometers), and such distance can be obtained through the relevant map data. Technical Barriers to Trade (TBT) is the biggest obstacle to China's export trade (Wang Yawing, 2012). After China's accession to the World Trade Organization, the electromechanical industry has become China's largest export industry, its proportion has been higher than the $50 \%$ of exports. However, the whole trade process also faces some technical barriers to trade, such as the technical standards and systems of the United States, Japan and other countries (Wang Yawing, 2007-2011). For the United States, its standards include UL certification system and FCC conformity assessment procedures (Zhou Xiangtan, 2008), CE Security Certification of the European Union and JIS certification of Jan pan as well as JATE certification (Liu Hong, 2007). Because such standards have certain differences with the relevant standards of China, they can easily affect the export trade of China's electromechanical products. In addition, Indonesia's SNI compulsory certification will also have an impact on China's electrical equipment exports in terms of technical requirements. OBOR has had a positive impact on China's cooperative trade with the relevant countries, especially in the politics, economy and cultural exchange and other aspects, which also make China and these countries try hard to complement each other. At present, developing countries occupy a large proportion of the countries covered by OBOR and their electricity consumptions are still in a low level. In the future, there will be a greater potential for growth, which also makes their power investments maintain a high growth rate and their electrical equipment demand grow faster, so the countries covered by OBOR will become the focus of cooperation.

\subsection{Regression Results of Parameter Estimation}

This paper chooses to use the Eviews8.0 software to process the sample data and carries on the least squares regression. The final result of the calculation is shown in table 3. By calculation results, it can see that when the significance level is $5 \%$, F statistic is higher than F0.05 $(7,65)=2.15$, that is, the whole linearity of the model is obviously able to be established under the confidence of $95 \%$. After substituting $F$ into the formula $R 2=1-(n-1) /(n-k-1+k F)$, the adjusted coefficient of determination is 0.55 and its overall linear characteristics are obvious. A significance test is then made to determine whether to keep it (Li Zinnia, 2010). If the significant level reaches 20\%, the tdistribution threshold whose degree of freedom is 60 t0.1 (60) $=1.296$, pop and the t-statistic of TC all cannot pass through T-test, so it can be expected that when the degree of freedom is 64 , they can still not pass $t$ test. The estimated parameter symbol of BL is just the opposite of the prediction and there is no real economic significance, so pop, bbl. and tic removed and the model is amended into:

$\log ($ export $)=\mu 1+\mu 2 *$ bra $+\mu 3 * \log ($ gap $)+\mu 4 * \log ($ ear $)+\mu 5^{*} \log$ (dist.)

The least squares regression is conducted again with the results shown in the above figure. According to Akanke information criterion and the Schwarz criterion, when the SC value decreases, the $\mathrm{F}$ value increases, and the adjusted coefficient of determination rises, so the overall linearity is significantly established and the fitting degree is higher. At the same time, the T-statistics of the of estimated coefficients of land, list and BR are 3.85,-10.09 and -6.04 respectively, and all of them have passed the T-test with a significant level of 5\% and a degree of freedom of 67 . The T-statistic of estimated coefficient of Lex is 1.92 and able to pass the T-test with a significance level of $10 \%$. The results show that the explanatory variables have significant influence on the explanatory variables.

Finally, the specific regression equation is concluded as:

$\log ($ export $)=16.91668-1.194639 * \mathrm{BR}+0.255686^{*} \log ($ gap $)-0.056677 * \log ($ ear $)-1.325610 * \log$ (dist.) 
Table 4. OLS regression results of the initial model

\begin{tabular}{|c|c|c|c|c|}
\hline Explanatory variables & $\begin{array}{l}\text { Estimated } \\
\text { coefficient }\end{array}$ & $\begin{array}{c}\text { Standard deviation of } \\
\text { the estimated } \\
\text { coefficient }\end{array}$ & T statistic & $\begin{array}{c}\text { Concomitant } \\
\text { probability of T } \\
\text { statistic }\end{array}$ \\
\hline $\log (\operatorname{gdp})$ & 0.392739 & 0.095460 & 4.114164 & 0.0001 \\
\hline $\log (p o p)$ & 0.005711 & 0.034448 & 0.165791 & 0.8689 \\
\hline $\log (\operatorname{exr})$ & -0.058138 & 0.031253 & -1.860197 & 0.0678 \\
\hline $\log$ (dist) & -1.232650 & 0.153924 & -8.008177 & 0.0000 \\
\hline TC & 0.320709 & 0.295941 & 1.083691 & 0.2828 \\
\hline $\mathrm{BL}$ & 0.429192 & 0.198964 & 2.157134 & 0.0350 \\
\hline $\mathrm{BR}$ & -1.098679 & 0.202987 & -5.412556 & 0.0000 \\
\hline $\mathrm{C}$ & 15.92259 & 1.357688 & 11.72773 & 0.0000 \\
\hline $\begin{array}{l}\text { Coefficient of } \\
\text { determination }\end{array}$ & 0.692534 & & $\begin{array}{c}\text { The mean of } \\
\text { dependent variable }\end{array}$ & 4.935735 \\
\hline $\begin{array}{l}\text { Adjusted coefficient } \\
\text { of determination }\end{array}$ & 0.552334 & & $\begin{array}{l}\text { Standard deviation of } \\
\text { dependent variable }\end{array}$ & 0.954917 \\
\hline Standard error & 0.571923 & & $\begin{array}{l}\text { Akaike information } \\
\text { criterion }\end{array}$ & 1.861899 \\
\hline $\begin{array}{l}\text { Residual sum of } \\
\text { squares }\end{array}$ & 19.62576 & & Schwarz criterion & 2.212455 \\
\hline $\begin{array}{l}\text { Log-likelihood } \\
\text { function value }\end{array}$ & -55.09743 & & $\begin{array}{l}\text { Hannan-Quinn } \\
\text { criterion }\end{array}$ & 2.001304 \\
\hline F statistic & 13.51435 & & D.W. value & 0.045757 \\
\hline $\begin{array}{l}\text { Concomitant } \\
\text { probability of F } \\
\text { statistic }\end{array}$ & 0.000000 & & & \\
\hline
\end{tabular}

Table 5. OLS regression results of the model after removing insignificant variables

\begin{tabular}{|c|c|c|c|c|}
\hline Explanatory Variables & $\begin{array}{l}\text { Estimated } \\
\text { coefficient }\end{array}$ & $\begin{array}{c}\text { Standard deviation of } \\
\text { the estimated } \\
\text { coefficient }\end{array}$ & T statistic & $\begin{array}{c}\text { Concomitant } \\
\text { probability of } \mathrm{T} \\
\text { statistic } \\
\end{array}$ \\
\hline $\log (\operatorname{gdp})$ & 0.255686 & 0.066409 & 3.850188 & 0.0003 \\
\hline $\log ($ exr $)$ & -0.056677 & 0.029583 & -1.915875 & 0.0599 \\
\hline Log (dist) & -1.325610 & 0.131316 & -10.09483 & 0.0000 \\
\hline $\mathrm{BR}$ & -1.194639 & 0.197665 & -6.043758 & 0.0000 \\
\hline $\mathrm{C}$ & 16.91668 & 1.170649 & 14.45068 & 0.0000 \\
\hline $\begin{array}{l}\text { Coefficient of } \\
\text { determination }\end{array}$ & 0.654868 & & $\begin{array}{c}\text { The mean of } \\
\text { dependent variable }\end{array}$ & 4.933696 \\
\hline $\begin{array}{l}\text { Adjusted coefficient } \\
\text { of determination }\end{array}$ & 0.617120 & & $\begin{array}{l}\text { Standard deviation of } \\
\text { dependent variable }\end{array}$ & 0.948326 \\
\hline Standard error & 0.586799 & & $\begin{array}{l}\text { Akaike information } \\
\text { criterion }\end{array}$ & 1.876170 \\
\hline $\begin{array}{l}\text { Residual sum of } \\
\text { squares }\end{array}$ & 22.03731 & & Schwarz criterion & 2.129133 \\
\hline $\begin{array}{l}\text { Log-likelihood } \\
\text { function value }\end{array}$ & -59.54213 & & $\begin{array}{l}\text { Hannan-Quinn } \\
\text { criterion }\end{array}$ & 1.976876 \\
\hline F statistic & 17.34807 & & D.W. value & 0.042339 \\
\hline $\begin{array}{l}\text { Concomitant } \\
\text { probability of F } \\
\text { statistic }\end{array}$ & 0.000000 & & & \\
\hline
\end{tabular}

\section{Analysis on the Potential of China's Electric Equipment Export Trade}

According to the regression equation, the potential exports of electrical equipment to various countries and regions covered or not covered by OBOR in the "ideal" state in 2016 are estimated to be compared with the actual trade volume, the results are as follows:

Lousing (2002) divides trading partners into three types according to the ratio between the estimated value and the actual value. If the ratio between the actual export value and the estimated export value in a country is greater than or equal to 1.25 , then it belongs to the potential re-modelling type, indicating that China's export trade of electrical equipment to this country has been more mature 
and the trade potential is small, that is, it needs to develop and nurture other conditions for promoting the relevant trade development. The trade countries or regions that belong to this type of electrical equipment export pattern are Germany, China's Hong Kong, USA, Mexico, Singapore, Vietnam and Malaysia. If the ratio between the actual export value and the estimated export trade volume in a country is between 1.25 and 0.83 , it belongs to the potential pioneering type that is, indicating that China's export potential has not been fully played here. The trade countries or regions that belong to this type of electrical equipment export pattern are India, Indonesia and Thailand. A majority of countries or regions covered by OBOR belong to this type, it can predict that the trade between China and these countries will be closer. If ratio between the actual export value and the estimated export trade volume in a country is less than 0.83 , it belongs to the huge potential type, that is, the export potential is very large here. The electrical equipment industry in China needs to seize this opportunity and vigorously develop export trade with these countries, such as Australia and Brazil. According to this ratio, different policy strategies can be adopted for the export of electrical equipment to different countries.

Table 6. Analysis on the trade potential of electrical equipment

\begin{tabular}{|c|c|c|c|c|}
\hline & $\begin{array}{l}\text { Export countries } \\
\text { or regions }\end{array}$ & $\begin{array}{c}\text { Estimated export } \\
\text { value (lnEXPORT' })\end{array}$ & $\begin{array}{l}\text { Actual export value } \\
(\text { lnEXPORT) }\end{array}$ & $\begin{array}{l}\text { Export trade potential value } \\
\text { (lnEXPORT'/lnEXPORT) }\end{array}$ \\
\hline \multirow{8}{*}{$\begin{array}{c}\text { Countries or regions } \\
\text { not covered by } \\
\text { OBOR }\end{array}$} & Germany & 5.547208 & 7.22790785 & 1.302981 \\
\hline & $\begin{array}{l}\text { China's Hong } \\
\text { Kong }\end{array}$ & 6.527841 & 7.861384858 & 1.204286 \\
\hline & Netherlands & 5.082474 & 6.093313925 & 1.198887 \\
\hline & United Kingdom & 5.350739 & 5.592357757 & 1.045156 \\
\hline & United States & 5.419918 & 7.421316121 & 1.369267 \\
\hline & Australia & 4.982076 & 3.285768784 & 0.659518 \\
\hline & Brazil & 4.195179 & 3.478131403 & 0.829078 \\
\hline & Mexico & 4.369766 & 6.63916559 & 1.519341 \\
\hline \multirow{10}{*}{$\begin{array}{l}\text { Countries or regions } \\
\text { covered by OBOR }\end{array}$} & Japan & 5.838972 & 6.88909413 & 1.179847 \\
\hline & Korea & 6.443339 & 7.202564394 & 1.117831 \\
\hline & India & 4.878074 & 4.408896168 & 0.903819 \\
\hline & Singapore & 4.354369 & 7.046220729 & 1.618195 \\
\hline & Vietnam & 4.570857 & 6.161198997 & 1.347931 \\
\hline & Indonesia & 3.921366 & 4.400380537 & 1.122155 \\
\hline & Malaysia & 4.330845 & 6.36782609 & 1.470343 \\
\hline & Russia & 4.169292 & 3.701283089 & 0.887749 \\
\hline & Thailand & 4.654562 & 5.69407797 & 1.223333 \\
\hline & $\begin{array}{l}\text { United Arab } \\
\text { Emirates }\end{array}$ & 3.967403 & 4.196101379 & 1.057644 \\
\hline
\end{tabular}

(Note: The data of exports of electrical equipment to Vietnam are replaced by that in 2015)

\section{Conclusion and Recommendation}

At present, domestic demand for electrical equipment is slowing in growth and the industry faces problems like overcapacity. As a result, electrical equipment prices continue to lower and China's electrical equipment industry is facing a transition downturn. Traditional electrical equipment enterprises have already started to find new market opportunities overseas. According to the regression model, the following suggestions are put forward for the export trade of China's electrical equipment.

The economic scale plays a decisive role in the bilateral comparative advantage, indicating that the main factor influencing the export trade flow of electrical equipment is the potential supply capacity of the exporter party. The larger the economic scale of the exporter party is, the greater the potential of the export supply (Shan Wanting, Yang Jibe, 2006). Therefore, the development of the domestic economy and the upgrade of the industrial structure and the improvement on the production level are the basic measures to develop foreign trade.

The non-ideal distance between China and the trade countries has a great negative effect on the export of electrical equipment, so improving the transportation condition is an important measure to 
promote the exportation of our country's electrical equipment. In recent years, China has made a lot of fruitful achievements in the cooperation with neighboring countries, for example, China has enhanced the trade cooperation with ASEAN and participated in the infrastructure construction and railway construction of the relevant countries. Such cooperation has improved the transport situation, and the development of two trade routes, i.e. land route and waterway, will also bring new development opportunities for China's electrical equipment export trade. The smoothness of trade routes will achieve a decrease in transport costs and tariffs.

The export trade potentials in the countries covered by OBOR are very considerable and these countries have a huge potential demand for power construction but no strong local enterprises, so it is recommended that the electrical equipment export to the countries and regions covered by OBOR can be included in China's strategic supporting measures for these countries. The relevant support policies and technical guidance can be mutually researched and developed.

As the cost of labor, capital and other factors needed by China's enterprises are rising, coupled with the exchange rate fluctuations and the anti-dumping and other trade protection measures implemented by import countries, the operating costs of China's enterprises have increased year by year. Therefore, China's electrical equipment export enterprises should transform as soon as possible and adjust the export structure. By reducing labor-intensive products, increasing technical input and developing high-tech-dominant and cost-effective products, the competitiveness of China's enterprises can be enhanced.

The establishment of the Asian Infrastructure Investment Bank and the establishment of Silk Road Fund of OBOR have expanded the scale of concessional loans, encouraged the state to provide various credit supports within the businesses for the export of electrical equipment, encouraged the participation of social capital into electrical equipment development projects, stabilized the export of traditional superior products and the products with intellectual property, great brand and high-tech attribute. The measures have further broadened the financing channels of import and export enterprises, and actively developed financial leasing. By improving the global credit management of Chinese financial institutions, they can provide supply chain financing for overseas businesses.

The export of electrical equipment of China has been subjected to the anti-dumping policies by many countries, therefore, it should consider establishing an interactive platform with the involvement of governments, enterprises and association organizations to achieve the function of timely early warning, information exchange, resource sharing, supervision and cooperation and the resistance to technical barriers, so as to grasp the situation of overall development, resolve outstanding contradictions, breaking trade barriers and achieve sustainable development.

\section{References}

[1]. Li Chengdu. Analysis on the status quo of electrical engineering and automation and its development trends [J]. Technology Innovation and Application, 2018 (01): 190-191.

[2]. Hu Yi, Yan Jilin, Quant Yi. Empirical study on the measurement of complementarity between China and the countries covered by OBOR and its influencing factors [J]. World Economic Research, 2017 (08): 51-63 + 136.

[3]. Zeng Zhao Rue, Chen Jingle, Wu Bahia. Analysis on the potential of China's wooden furniture export trade under OBOR [J]. Forestry Economics, 2017, 39 (04): 35-41.

[4]. Pan Yang, Zhou Shu Hua, Wen Yanking. Investigation on the impact of technical barriers to trade on exports of China - A case study of the US's CPSC and the European RAPEX [J]. Zhejiang Economy, 2016 (20): 34-36.

[5]. Qin Lankan. Research on the silk export trade potential of China under OBOR. [D] Zhejiang Sictech University, 2016.

[6]. Wang Ting. Analysis on Zhejiang's garment export trade potential under OBOR [D]. Zhejiang Sic-tech University, 2016. 
[7]. Kong Qingfeng, Dong Hogweed. Measurement the level of trade facilitation and trade potential of the countries covered by OBOR [J]. International Trade Issues, 2015 (12): 158-168.

[8]. Liao Mingzhong. Estimation on China's export potential in the countries covered by the OBOR [J]. China Opening Journal, 2015 (03): 64-67.

[9]. Li Penguin. Analysis on the impact of EU's technical barriers to trade on China's exports of mechanical and electrical products [D]. Hebei University, 2015.

[10]. Zheng Gooey. Import and export situation of the electrical industry and the issues to be concerned about in the first half year [J]. Electrical Industry, 2014 (08): 44-47.

[11]. Lin Haitian. An empirical analysis on the impact of China's intellectual property protection on its exports of electrical and electronic equipment to the United States [D]. Liaoning University, 2012.

[12]. Wang Yawing. The biggest obstacle caused by technical barriers to trade to China's export trade [J]. Corporate Economics, 2012, 31 (03): 5-10.

[13]. Yan Li. Analysis on the EU's technical barriers to trade facing China's exports of electromechanical products [D]. Dongle University of Finance and Economics, 2011.

[14]. Bi Yanbu, Shi Bo. Calculation and analysis of China's trade potential in five central Asian countries - research on trade complementarity index and gravity model [J]. Asia Pacific Economic Review, 2010 (03): 47-51.

[15]. Han Yan. Analysis on the competitiveness of China's service trade [J]. Economic Research Guide, 2008 (18): 187-188.

[16]. Lin Jian, Hue Shangri. Empirical analysis on the influencing factors of China's fruit export trade [J]. Agricultural Technology Economics, 2008 (04): 95-101.

[17]. Huang Eying, Zhang Yu. An empirical analysis on the new trend of China's foreign trade based on the extended trade gravity model [J]. International Economics and Trade Research, 2008 (02): 23-28.

[18]. Wang Youngman, Fu Buoying. A review of the research on technical barriers to trade between Europe, the United States and China [J]. Economic Latitude, 2006 (04): 55-58.

[19]. Shi Hoaxing, Go Haying. New progress of trade gravity model and its application in China [J]. Finance and Trade Research, 2005 (03): 27-32. 